\title{
The impact of maternal protein restriction during rat pregnancy upon renal expression of angiotensin receptors and vasopressin-related aquaporins
}

\author{
Ruth Cornock', Simon C Langley-Evans ${ }^{1 *}$, Ali Mobasheri ${ }^{2}$, Sarah McMullen ${ }^{1}$
}

\begin{abstract}
Background: Maternal protein restriction during rat pregnancy is known to impact upon fetal development, growth and risk of disease in later life. It is of interest to understand how protein undernutrition influences the normal maternal adaptation to pregnancy. Here we investigated the mechanisms regulating renal haemodynamics and plasma volume during pregnancy, in the context of both normal and reduced plasma volume expansion. The study focused on expression of renal angiotensin receptors (ATR) and vasopressin-related aquaporins (AQP), hypothesising that an alteration in the balance of these proteins would be associated with pregnancy per se and with compromised plasma volume expansion in rats fed a low-protein diet.

Methods: Female Wistar rats were mated and fed a control (18\% casein) or low-protein ( $9 \%$ casein) diet during pregnancy. Animals were anaesthetised on days 5, 10, 15 and 20 of gestation ( $n=8 /$ group/time-point) for determination of plasma volume using Evans Blue dye, prior to euthanasia and collection of tissues. Expression of the ATR subtypes and AQP2, 3 and 4 were assessed in maternal kidneys by PCR and western blotting. 24 nonpregnant Wistar rats underwent the same procedure at defined points of the oestrous cycle.

Results: As expected, pregnancy was associated with an increase in blood volume and haemodilution impacted upon red blood cell counts and haemoglobin concentrations. Expression of angiotensin II receptors and aquaporins 2, 3 and 4 was stable across all stages of the oestrus cycle. Interesting patterns of intra-renal protein expression were observed in response to pregnancy, including a significant down-regulation of AQP2. In contrast to previous literature and despite an apparent delay in blood volume expansion in low-protein fed rats, blood volume did not differ significantly between groups of pregnant animals. However, a significant down-regulation of $A T_{2} R$ protein expression was observed in low-protein fed animals alongside a decrease in creatinine clearance.
\end{abstract}

Conclusion: Regulatory systems involved in the pregnancy-induced plasma volume expansion are susceptible to the effects of maternal protein restriction.

\section{Background}

Human pregnancy is associated with a $30-50 \%$ increase in plasma volume, beginning early in the first trimester and peaking at around 32 weeks of gestation [1]. Coupled with an expansion of red blood cell mass, this leads to an increase in blood volume [2]. Failure to

\footnotetext{
* Correspondence: Simon.Langley-Evans@Nottingham.ac.uk

'School of Biosciences, University of Nottingham, Sutton Bonington Campus, Loughborough, LE12 5RD, UK

Full list of author information is available at the end of the article
}

expand circulating volume is associated with intrauterine growth restriction and hypertensive complications of pregnancy $[1,3,4]$. A similar profile of plasma volume expansion occurs in rodents during pregnancy [5], providing a useful model with which to examine the molecular and physiological mechanisms of volume expansion and the impact of modifiable environmental factors.

The events leading to plasma volume expansion are not fully understood, but evidence suggests that it is 
triggered by a fall in systemic vascular tone [6]. This is thought to be followed by compensatory activation of volume-restoring mechanisms, including activation of the renin-angiotensin-aldosterone (RAAS) and argininevasopressin (AVP) systems $[7,8]$, leading to renal sodium and water retention. The plasma volume expansion is associated with a substantial increase in effective renal plasma flow (ERPF) and glomerular filtration rate (GFR) from as early as the sixth week of human pregnancy $[9,10]$. The initial trigger for this series of events remains poorly understood. Activity of the ovaries or corpus luteum is thought to be responsible for the initial peripheral vasodilation, as similar changes are observed in pseudopregnant rats [11] and in women in the luteal phase of the menstrual cycle [12]. A role for the fetoplacental compartment has also been suggested, based on fetal reduction experiments in rodents [13] and the greater volume expansion observed in human twin pregnancies [14].

This study aimed to use a rat model of protein restriction to investigate the molecular mechanisms underlying the alterations in renal haemodynamics and plasma volume during pregnancy and to determine the sensitivity of such mechanisms to dietary insult. Low-protein diets are known to decrease urine concentrating ability in humans and rats [15], and are suggested to attenuate plasma volume expansion during pregnancy in rats $[16,17]$. This is of major interest as offspring from lowprotein fed rats develop a range of metabolic disorders in later life, including hypertension, insulin resistance and dyslipidaemia $[18,19]$. Similar phenotypes have been observed in response to a range of other maternal dietary manipulations. The mechanisms through which such programming of disease risk occurs are not fully understood [20] and the contributions of maternal physiological responses and placental functions have been largely overlooked.

It is possible that inadequate plasma volume expansion may be one mechanism by which maternal diet impacts on the critical developmental processes related to postnatal metabolic disease. Compromised haemodilution and renal adaptation may adversely impact upon placental perfusion and hence the transfer of nutrients to the developing fetus. Inadequate nutrient supply or endocrine signalling may have irreversible effects upon organ development and therefore reduce functional capacity in later life [20]. The current study focused on renal expression of the angiotensin receptors (ATR) and the vasopressin-related aquaporins (AQP) during the oestrous cycle and pregnancy. It has been suggested that activation of arterial baroreceptors in response to peripheral vasodilation leads to nonosmotic AVP release and activation of the RAAS, over-riding the suppression of AVP release which would normally be observed in a hypo-osmotic state and thus contributing to water and sodium retention during pregnancy [21]. It has also been shown that the reduction in urine concentrating ability observed in low-protein fed rats is associated with a decrease in AQP2 protein in the inner medullary tip [15]. We therefore hypothesised that an alteration in the balance of ATR subtypes and the expression of renal $A Q P s$ would be observed in the pregnant versus non-pregnant state, and would result in a reduced plasma volume expansion in low-protein fed rats.

\section{Methods}

\section{Animal procedures}

All experiments were carried out in accordance with the 1986 Animals (Scientific Procedures) Act. 64 virgin female Wistar rats (Harlan Ltd, UK) were mated at weights of 200-250 g. Upon confirmation of mating by the presence of a semen plug on the cage floor, rats were assigned to either a control diet $(180 \mathrm{~g}$ casein $/ \mathrm{kg})$ or a low-protein diet ( $90 \mathrm{~g}$ casein $/ \mathrm{kg}$ ) as described previously [22]. Within each dietary group, creatinine clearance and plasma volume were estimated at days 5,10 , 15 and 20 of gestational age (GA, $n=7-9$ in each dietary GA group) prior to euthanasia. A further group of non-pregnant virgin female Wistar rats $(\mathrm{n}=24)$ were maintained on a standard laboratory chow diet (Harlan Ltd) and their stage of oestrous was determined daily by vaginal swabbing. According to microscopic evaluation of the cell types present, non-pregnant rats were classified as pro-oestrous, oestrous, met-oestrous and di-oestrous, and 6 animals were euthanased per stage of oestrous following estimation of creatinine clearance and plasma volume. Following euthanasia of pregnant and non-pregnant animals, one kidney was snap frozen and stored at $-80^{\circ} \mathrm{C}$ for molecular analyses.

\section{Creatinine clearance}

On the day prior to euthanasia, animals were housed in metabolism cages for 24 hour collection of urine. UK Home Office restrictions did not allow animals to be housed in metabolism cages for more than 24 hours. An aliquot of urine was frozen at $-20^{\circ} \mathrm{C}$ until analysed. Plasma and urine creatinine concentrations were determined by the Jaffé alkaline picrate method [23]. A standard curve was prepared using commercially available creatinine standards (Sigma, UK). A working reagent was created at the time of sample analysis by mixing equal volumes of three solutions: A ( 4.4 g sodium hydroxide, $9.5 \mathrm{~g}$ trisodium phosphate, $9.5 \mathrm{~g}$ sodium tetraborate; in $400 \mathrm{mls}$ distilled water), B (4\% (w/v) sodium dodecyl sulphate) and C (picric acid). $200 \mu \mathrm{l}$ of working reagent was added to $20 \mu \mathrm{l}$ aliquots of samples and standards on a microplate in duplicate. Following $30 \mathrm{~min}$ utes incubation at room temperature on an orbital 
shaker, the absorbance was read at $492 \mathrm{~nm} .10 \mu \mathrm{l}$ of $30 \%(\mathrm{v} / \mathrm{v})$ acetic acid was then added to each well, the microplate incubated at room temperature for a further five minutes and the absorbance read at $492 \mathrm{~nm}$. The difference between absorbance before and after acidification by acetic acid was calculated. Creatinine clearance was estimated as (urinary creatinine $[\mu \mathrm{mol} / \mathrm{l}] \times$ volume urine produce in 24 hours $[\mathrm{mls}]$ )/(plasma creatinine $[\mu \mathrm{mol} / \mathrm{l}] \times 1440$ [minutes]). The intra- and inter-assay coefficients of variation for plasma creatinine were $3.1 \%$ and $5.5 \%$ respectively. The intra and inter-assay coefficients of variation for urinary creatinine were $3.5 \%$ and $0.5 \%$ respectively.

\section{Blood and plasma volume}

The method for determining blood and plasma volume was based on a previously published method [24]. Under isofluorane anaesthesia, a cannula was inserted into the left iliac vein through which an initial (baseline) blood sample of $1 \mathrm{ml}$ was taken for use as a plasma blank and for analyses of plasma creatinine and haematological parameters. $0.3 \mathrm{ml}$ Evans Blue Dye $(0.5 \mathrm{mg} / \mathrm{ml})$ was injected via the cannula, followed by a flush with $0.5 \mathrm{ml}$ saline. The dye was allowed to circulate for five minutes, after which a final blood sample was taken. The animal was then euthanased by injection of sodium pentobarbitone, with death confirmed by cervical dislocation. Blood was collected into EDTA microtubes and centrifuged at $3000 \mathrm{rpm}$ for collection of plasma, which was stored at $-20^{\circ} \mathrm{C}$ prior to analyses.

$75 \mu \mathrm{l}$ of the baseline and final plasma samples were added in duplicate to a 96 well microplate. Plates were read immediately at $620 \mathrm{~nm}$ (Tecan Sunrise, Magellan Software version 4.0) and the absorbance of the baseline plasma samples was subtracted from the absorbance of the final plasma samples collected 5 minutes after dye injection. Baseline plasma samples from each animal acted as a blank for that individual animal. Plasma volume was calculated as (milligrams dye injected/ plasma dye concentration). The inter- and intra-assay coefficients of variation for Evans Blue dye concentrations were $10.0 \%$ and $4.3 \%$ respectively. Blood volume was calculated as (plasma volume)/(1-(0.009 $\times$ haematocrit)) using an F-cells ratio of 0.9 to account for the difference between whole body and venous haematocrit (Blair \& Mickelsen 2006).

\section{Haematology analyses}

Haematological parameters were measured in an aliquot of the baseline blood sample using the Vet Medonic CA 620 (Boule Medical, Sweden) within three hours of collection from the animal.

\section{Western blotting}

Tissues were homogenised in an extraction buffer containing $50 \mathrm{mM}$ Tris/HCL and $5 \mathrm{mM}$ EDTA. Protein concentration was determined by the Bradford method [25] and samples adjusted to equal concentrations. Samples were diluted with an equal volume of loading buffer [4\% (w/v) SDS, $125 \mathrm{mM}$ Tris/ $\mathrm{HCl} \mathrm{pH} 6.8,20 \%$ (v/v, 87\%) glycerol, $0.1 \mathrm{M}$ dithiothreitol] and heated at $90^{\circ} \mathrm{C}$ for 5 minutes before being run on SDS-polyacrylamide gels. Electrophoresis was carried out in a 10× Tris/glycine/SDS running buffer (National Diagnostics, USA). Following separation by electrophoresis, proteins were transferred to nitrocellulose membrane (GE Healthcare, UK). Blots were probed with the following anti-rat antibodies: $\mathrm{AT}_{1} \mathrm{R}$ diluted 1:500 (Santa Cruz, USA), AQP2 [26], AQP3 [27] and AQP4 [27], diluted 1:5000 (affinity purified rabbit anti-rat AQP2 antibodies, was kindly provided by Dr. David Marples, University of Leeds), $\mathrm{AT}_{2} \mathrm{R}$ diluted 1:45,000 (Abcam, UK) and tubulin diluted 1:30,000 (Abcam). The $\mathrm{AT}_{1} \mathrm{R}$ antibody did not distinguish between $A T_{1 a} R$ and $A T_{1 b} R$ isoforms. Blots were then treated with goat anti-rabbit horseradish peroxidise linked secondary antibody (GE Healthcare). Blots treated with $A Q P 2$ and $A T_{1} R$ antibodies were developed using Enhanced Chemiluminescence (ECL, Biological Industries, Israel). Blots treated with $\mathrm{AT}_{2} \mathrm{R}$ and tubulin were developed using ECL Advance (GE Healthcare). Blots were exposed to Hyperfilm ECL (GE Healthcare) to visualise the protein bands, which were quantified using a Quantity-One Multi Analyst system (Bio-Rad, UK). Protein expression was normalised to tubulin expression to correct for any discrepancies in the loading of samples onto the gel.

\section{RNA extraction and real-time RT-PCR}

RNA was extracted from snap-frozen kidney tissue by the TRIzol procedure (Invitrogen, UK) and subjected to DNAse treatment (Promega, UK), phenol-chloroform extraction and ethanol precipitation. RNA was reverse transcribed using Moloney murine leukemia virus (MMLV) reverse transcriptase (Promega). Real-time PCR primers and a probe were designed for AQP2 using Primer Express software (version 1.5; Applied Biosystems) from the DNA sequence GenBank Accession no. NM_012909. The primer sequences were as follows: $\mathrm{AQP} 2$ forward primer 5'-CCATTGGTTTCTCTGTTACCCTG-3', reverse primer 5'-CGGGCTGGCTTCATGGAG-3', probe 5'CCACCTCCTTGGGATCTATTTCACCGG-3'. Primers were ordered from MWG Biotech, Germany. Primer and probe sequences for $\mathrm{AT}_{1 \mathrm{a}} \mathrm{R}, \mathrm{AT}_{2} \mathrm{R}$ and $\beta$-actin are published elsewhere [28]. Real Time PCR was performed using a Lightcycler 480 PCR machine (Roche, UK). 


\section{Statistical analysis}

Data is presented throughout as means \pm standard error of the mean (SEM). Data was analysed using SPSS version 16.0. To assess the effect of pregnancy per se, an independent $\mathrm{t}$-test was used to compare means between non-pregnant and pregnant control fed animals, using all data from each condition irrespective of gestational age or stage of oestrus. In the pregnancy data sets, the effects of gestational age and diet during pregnancy were assessed by two-way analysis of variance. In the figures and tables, superscript letters are used to indicate outcomes of post hoc tests (Bonferroni) applied where ANOVA showed a main effect of diet or gestational age. Posthoc tests cannot be performed on interactions of these factors and so no symbols are shown where only interactive effects were noted. The statistical significance of the main factors and the interaction between them are presented throughout. In the oestrous cycle data sets, the effect of stage of oestrous was assessed by one-way analysis of variance. A probability of $<5 \%$ was considered statistically significant.

\section{Results}

\section{Weight, haematological parameters and pregnancy} outcome

At the start of the experiment the two dietary groups were of similar weight (control $240 \pm 5 \mathrm{~g}$, low protein $247 \pm 5$ g, not significantly different). There was no significant effect of a maternal low-protein diet on maternal body weight or pregnancy weight gain at any stage of gestation (Table 1). There was a small but statistically significant increase in maternal kidney weight as pregnancy progressed in both the control and low-protein fed groups (Table 1, GA: $P<0.05$ ). Significant fluctuations in kidney weight were also observed in non-pregnant rats during the oestrous cycle (Table $2, P<0.05$ ). Urine output was highly variable among pregnant rats but was not significantly influenced by gestational age or diet (Table 1). Non-pregnant animals (Table 2) produced less urine than pregnant animals $(P=0.031)$, but urine volume was not influenced by stage of oestrus cycle.

There was no effect of maternal diet on litter size or on mean fetal or placental weight at gestational age 15 or 20. Maternal red blood cell count, haemoglobin concentration and haematocrit were all unaffected by gestational age and maternal diet (Table 1). These parameters did not vary according to stage of the oestrous cycle (Table 2). Pregnant animals exhibited significantly decreased maternal red blood cell count $(6.6 \pm$ 0.1 vs. $\left.7.2 \pm 0.110^{6} / \mathrm{mm}^{3}, P<0.05\right)$ haemoglobin concentration $(12.4 \pm 0.2$ vs. $13.5 \pm 0.2 \mathrm{~g} / \mathrm{dl}, P<0.01)$ and haematocrit $(33.7 \pm 0.7$ vs. $36.5 \pm 0.4 \%, P<0.05)$ in comparison to non-pregnant controls.
Blood volume and creatinine clearance during pregnancy There was a significant effect of gestational age on plasma (data not shown) and blood volume (Figure 1A), with significant expansion of volume being apparent by day 15 in control animals ( $P=0.036$ compared to nonpregnant animals at oestrus). Although it appeared that there was a delay in the expansion of blood volume in the low-protein fed rats leading to a difference between groups on day 15 of pregnancy, there was no statistically significant interaction between gestational age and diet for either plasma or blood volume. Among the nonpregnant rats there was significant variation in blood volume across the oestrus cycle, with significantly greater volume noted at di-oestrus (Figure 1B).

There was a significant interaction between gestational age and diet in their effects on creatinine clearance during pregnancy (Figure 1C). Whilst clearance remained relatively constant in the control animals, there was a decrease in creatinine clearance in low-protein fed animals between days 10 and 20 of gestation, leading to significantly lower clearance rates on day 20 of gestation.

\section{Angiotensin receptor expression during pregnancy}

There was no difference in the level of $\mathrm{AT}_{1 \mathrm{a}} \mathrm{R}$ mRNA expression (Figure 2A) between pregnant and non-pregnant rats. It was not possible to compare protein expression between these states due to technical reasons. As pregnancy progressed from GA5 to GA20, there was no alteration in protein or mRNA expression levels and there was no effect of dietary treatment during pregnancy (Figure 3A \&3C). Expression of $\mathrm{AT}_{1} \mathrm{R}$ protein and mRNA did not vary across the stages of the oestrus cycle (Figure 3B \&3D).

The expression of $\mathrm{AT}_{2} \mathrm{R}$ mRNA and protein did not differ significantly between non-pregnant and control fed pregnant animals (Figures 2B, C) and there was no significant effect of gestational age on expression of $\mathrm{AT}_{2} \mathrm{R}$ mRNA or protein (Figure 4A \&4C). However, expression of $\mathrm{AT}_{2} \mathrm{R}$ protein was significantly decreased in response to a low-protein diet across all gestational ages (Figure 4A, Diet: $P<0.05$ ). Expression of $\mathrm{AT}_{2} \mathrm{R}$ protein and mRNA (Figure 4B \&4D) were not significantly influenced by stage of oestrus.

\section{Expression of $A Q P 2, A Q P 3$ and AQP4 during pregnancy}

The expression of AQP2 protein was significantly decreased in pregnancy in comparison to levels at oestrous (Figure 2D, $P<0.05$ ). This was associated with a $35 \%$ decrease in AQP2 mRNA expression overall (Figure 2 E, $P<0.05)$. As pregnancy progressed from GA5 to GA20 there was a significant interaction between gestational age and maternal diet, which reflected an earlier down-regulation of AQP2 in low-protein fed animals in comparison to controls (Figure 5A, GA*Diet $P<0.05$ ). 
Table 1 Maternal weight and haematological parameters and litter characteristics at days 5, 10, 15 and 20 of gestation in rats fed a control or low-protein diet from mating.

\begin{tabular}{|c|c|c|c|c|c|c|c|c|}
\hline & \multirow[t]{2}{*}{ Diet } & \multicolumn{4}{|c|}{ Gestational age $(n=7-9)$} & \multicolumn{3}{|c|}{ Statistical significance } \\
\hline & & 5 & 10 & 15 & 20 & GA & Diet & GA* Diet \\
\hline \multirow[t]{2}{*}{ Body weight (g) } & Control & $257.3 \pm 10.7^{d}$ & $312.8 \pm 6.2^{c}$ & $325.3 \pm 12.1^{b}$ & $372.8 \pm 15.0^{\mathrm{a}}$ & $P<0.001$ & NS & NS \\
\hline & Low protein & $277.8 \pm 8.2^{d}$ & $302.6 \pm 10.7^{c}$ & $347.3 \pm 7.4^{b}$ & $346.7 \pm 12.8^{\mathrm{a}}$ & & & \\
\hline \multirow[t]{2}{*}{ Pregnancy weight gain (g) } & Control & $26.2 \pm 2.0^{d}$ & $63.8 \pm 6.8^{c}$ & $82.7 \pm 7.2^{\mathrm{b}}$ & $137.3 \pm 7.9^{\mathrm{a}}$ & $P<0.05$ & NS & NS \\
\hline & Low protein & $19.8 \pm 3.0^{d}$ & $60.4 \pm 6.3^{c}$ & $90.2 \pm 5.2^{b}$ & $122.7 \pm 13.2^{\mathrm{a}}$ & & & \\
\hline \multirow[t]{2}{*}{ Kidney weight (g) } & Control & $1.04 \pm 0.04^{b}$ & $1.10 \pm 0.04$ & $1.10 \pm 0.04^{a}$ & $1.11 \pm 0.06$ & $P<0.05$ & NS & NS \\
\hline & Low protein & $0.88 \pm 0.11^{b}$ & $1.11 \pm 0.05$ & $1.14 \pm 0.04^{\mathrm{a}}$ & $0.97 \pm 0.05$ & & & \\
\hline \multirow[t]{2}{*}{ Urine volume (ml/24 hour) } & Control & $18.3 \pm 3.5$ & $26.09 \pm 4.7$ & $22.4 \pm 5.6$ & $29.5 \pm 7.4$ & NS & NS & NS \\
\hline & Low protein & $18.2 \pm 2.9$ & $26.6 \pm 6.7$ & $21.4 \pm 3.1$ & $20.5 \pm 6.0$ & & & \\
\hline \multirow[t]{2}{*}{ Litter size (pups/litter) } & Control & & & $15 \pm 1$ & $14 \pm 1$ & NS & NS & NS \\
\hline & Low protein & & & $14.0 \pm 1$ & $14 \pm 1$ & & & \\
\hline \multirow[t]{2}{*}{ Mean fetal weight (g) } & Control & & & $0.30 \pm 0.01$ & $3.66 \pm 0.11$ & NS & NS & NS \\
\hline & Low protein & & & $0.29 \pm 0.01$ & $3.37 \pm 0.13$ & & & \\
\hline \multirow[t]{2}{*}{ Mean placental weight (g) } & Control & & & $0.22 \pm 0.01$ & $0.51 \pm 0.03$ & NS & NS & NS \\
\hline & Low protein & & & $0.22 \pm 0.01$ & $0.53 \pm 0.07$ & & & \\
\hline \multirow[t]{2}{*}{ Red blood cells $\left(10^{6} / \mathrm{ml}\right)$} & Control & $6.0 \pm 0.7$ & $6.3 \pm 0.7$ & $6.6 \pm 0.3$ & $6.5 \pm 0.2$ & NS & NS & NS \\
\hline & Low protein & $7.4 \pm 0.1$ & $6.9 \pm 0.1$ & $6.7 \pm 0.2$ & $6.3 \pm 0.2$ & & & \\
\hline \multirow[t]{2}{*}{ Haemoglobin $(\mathrm{g} / \mathrm{dL})$} & Control & $11.3 \pm 1.3$ & $11.8 \pm 1.3$ & $12.4 \pm 0.5$ & $11.9 \pm 0.4$ & NS & NS & NS \\
\hline & Low protein & $13.9 \pm 0.2$ & $13.0 \pm 0.3$ & $12.6 \pm 0.2$ & $11.6 \pm 0.3$ & & & \\
\hline \multirow[t]{2}{*}{ Haematocrit (\%) } & Control & $30.6 \pm 3.6$ & $31.6 \pm 3.6$ & $33.3 \pm 1.8$ & $32.6 \pm 1.2$ & NS & NS & NS \\
\hline & Low protein & $37.8 \pm 0.5$ & $35.3 \pm 0.7$ & $33.8 \pm 0.5$ & $31.3 \pm 0.9$ & & & \\
\hline
\end{tabular}

Data is presented as mean \pm SEM. Data was analysed by two-way ANOVA and the statistical significance of main factor and interaction effects is shown (NS - not significant). Superscripts denote the statistical significance of post hoc analysis conducted where there was a significant effect of gestational age (superscript letters indicate $a>b>c>d, P<0.05)$.

There was also an interaction between gestational age and maternal diet in their effects on AQP2 mRNA expression, resulting in a difference between control and low-protein fed animals on GA5 only (Figure $5 \mathrm{C}$, GA*Diet $P<0.05)$. The protein expression of AQP3 and AQP4 did not differ between pregnant and non-pregnant animals (data not shown) and was not affected by gestational age or maternal diet (Figure 6A \&6C). The expression of AQP2 protein and mRNA (Figure 5B $\& 5 \mathrm{D}$ ) and of AQP3 and 4 proteins (Figure 6B \&6D) were similar over all stages of the oestrus cycle.

\section{Discussion}

This study used a rat model of protein restriction to investigate the molecular mechanisms regulating renal haemodynamics and plasma volume during pregnancy and the sensitivity of these processes to dietary insult. The study focused on renal expression of the angiotensin receptors and the vasopressin-related aquaporins (AQPs), hypothesising that an alteration in the balance of these proteins would be associated with pregnancy per se and with the maternal response to protein restriction.

Table 2 Weight and haematological parameters in control fed Wistar rats at each stage of the oestrous cycle

\begin{tabular}{|c|c|c|c|c|c|}
\hline & \multicolumn{4}{|c|}{ Stage of oestrus cycle ( $n=6$ per stage) } & \multirow[t]{2}{*}{$P$} \\
\hline & Proestrus & Oestrus & Metestrus & Dioestrus & \\
\hline Body weight (g) & $234.2 \pm 8.9$ & $256.5 \pm 11.6$ & $233.9 \pm 3.7$ & $244.8 \pm 9.8$ & NS \\
\hline Kidney weight (g) & $0.88 \pm 0.02^{b}$ & $0.92 \pm 0.05$ & $0.97 \pm 0.02$ & $1.01 \pm 0.02^{\mathrm{a}}$ & $P<0.05$ \\
\hline Urine volume (ml/24 hour) & $16.7 \pm 3.0$ & $18.4 \pm 4.5$ & $18.7 \pm 4.7$ & $15.3 \pm 1.6$ & NS \\
\hline Red blood cells $\left(10^{6} / \mathrm{ml}\right)$ & $7.4 \pm 0.2$ & $7.3 \pm 0.1$ & $7.5 \pm 0.2$ & $7.0 \pm 0.1$ & NS \\
\hline Haemoglobin (g/dL) & $14.0 \pm 0.5$ & $13.4 \pm 0.2$ & $13.7 \pm 0.3$ & $13.2 \pm 0.2$ & NS \\
\hline Haematocrit (\%) & $37.9 \pm 1.3$ & $36.1 \pm 0.7$ & $36.9 \pm 0.7$ & $35.5 \pm 0.8$ & NS \\
\hline
\end{tabular}

Data is presented as mean \pm SEM. Data was analysed by one-way ANOVA and the statistical significance of the effect of stage of oestrous is shown (NS - not significant). Superscripts denote the statistical significance of posthoc analysis, which were conducted where a significant main factor effect was found (superscript letters indicate $a>b, P<0.05$ ). 


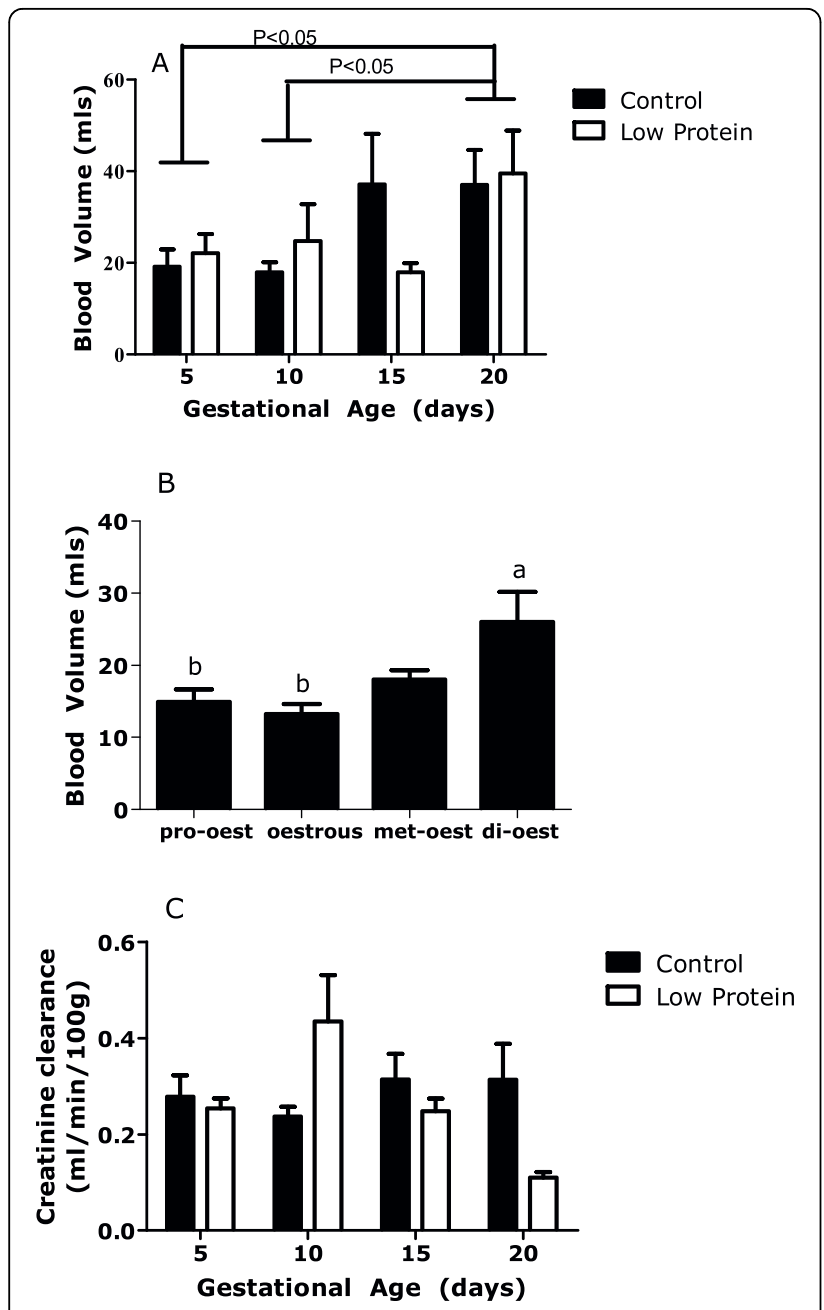

Figure 1 Blood volume of pregnant and non-pregnant rats. Blood volume in rats fed control or low protein diet during pregnancy $(A, n=7-9)$ and in non-pregnant rats at different stages of the oestrus cycle $(B, n=6)$ Creatinine clearance $(C, n=4-8)$ in rats fed a control or low-protein diet during pregnancy. Data is presented as mean \pm SEM and was analysed by one or two-way ANOVA, as described in the methods section. There was a significant effect of gestational age on blood volume $(P<0.05)$, but no effect of maternal diet. Blood volume varied with stage of oestrus (superscript letters denote $a>b, P<0.05$ ) There was $a$ significant interaction between gestational age and diet in their effects on creatinine clearance $(P<0.05)$.

\section{Effects of pregnancy per se}

In agreement with previous literature, an expansion of plasma and blood volume was observed during pregnancy. Blood volume increased in comparison to that observed in rats at oestrous by $45 \%$ at day 5 of pregnancy and $180 \%$ at day 20 . As expected, the expansion in blood volume was coupled with evidence of haemodilution, as reflected by decreased maternal haematocrit and haemoglobin concentrations
To our knowledge, this is the first study to characterise renal angiotensin receptor protein expression through the course of pregnancy in the rat. No change in $\mathrm{AT}_{1} \mathrm{R}$ or $\mathrm{AT}_{2} \mathrm{R}$ mRNA expression compared to the non-pregnant state was observed and there was no cumulative change in $\mathrm{AT}_{1} \mathrm{R}$ or $\mathrm{AT}_{2} \mathrm{R}$ expression as pregnancy progressed from day 5 to 20. Although a recent paper reported no effect of pregnancy on $A T_{1} R$ expression [29], the study focused on mRNA expression only. Previously Bedard et al., [30] reported down-regulation of $\mathrm{AT}_{1} \mathrm{R}$ protein expression in the pregnant rat kidney. Observations in non-pregnant animals suggest that binding to $\mathrm{AT}_{1} \mathrm{R}$ is inhibited by $17 ß$-oestradiol [31]. Progesterone is another endocrine factor that is known to inhibit expression of AT1R and which could have a potent influence during pregnancy [32]. However, in the current study we found that mRNA and protein expression was unchanged in pregnancy. It is important to note that pregnancy-induced plasma volume expansion occurs in the context of systemic and intra-renal vasodilation [33], and an increase in ERPF and GFR $[9,10]$. This is reflected in the relative systemic pressor resistance to AngII found in pregnancy [34,35]. Although $\mathrm{AT}_{1} \mathrm{R}$ might be envisaged as having effects upon multiple sodium and water transport systems in the nephron, the localization of this receptor is in the proximal tubule. Promotion of sodium reabsorption here is in proportion to GFR and would not impact upon blood volume. Alternatively, although systemic vascular responses to AngII are attenuated, others have shown a normal renal vascular response to AngII [36]. It is possible that site-specific up-regulation of intrarenal $\mathrm{AT}_{1} \mathrm{R}$ may therefore mediate vasoconstriction of the medullary vasculature and contribute to the blunting of the acute pressure natriuresis curve observed in pregnancy [37]. $\mathrm{AT}_{2} \mathrm{R}$ has been suggested to have a role in systemic and renal vasodilation [38] although a role for this receptor in altered renal function during pregnancy has not been fully established. However Ferreira and colleagues observed a 30 fold increase in the mRNA expression of one of the relaxin receptors (LGR7) in the renal cortex. This could result in significant renal vasodilation, allowing glomerular filtration to rise during pregnancy [38]. Relaxin has been suggested to have a major role in both renal and systemic vasodilation in pregnancy [39].

There was a significant down-regulation of the expression of AQP2 protein during pregnancy to $43 \%$ of the level observed in non-pregnant animals. AQP2 is the predominant vasopressin-sensitive water channel, cloned and located in the principal cells of the kidney collecting duct [40]. Evidence suggests that the decrease in arterial baroreceptor stretch during pregnancy leads to 


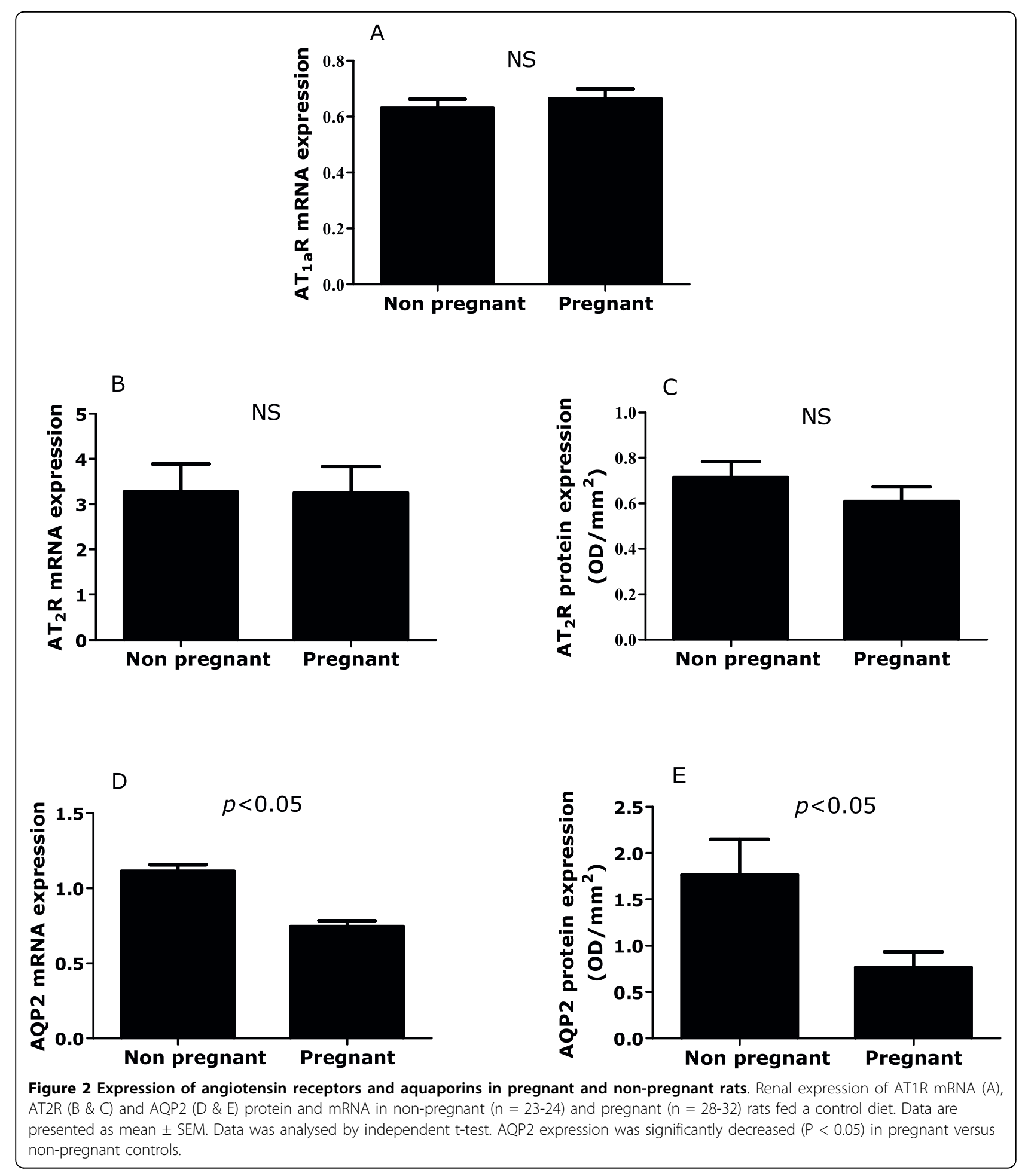

non-osmotic vasopressin release [21] which activates the vasopressin $V_{2}$ receptors $\left(V_{2} R s\right)$ and the adenylate-cyclic AMP pathway in the collecting duct, resulting in increased AQP2 gene transcription and shuttling of AQP2 water channels to the apical membranes of principal cells. Whilst translocation of AQP2 from cytosolic vesicles to the apical membrane mediates the acute response to AVP stimulation [41], long-term regulation of collecting duct water permeability is characterised by an increase in AQP2 mRNA and protein $[42,43]$. 


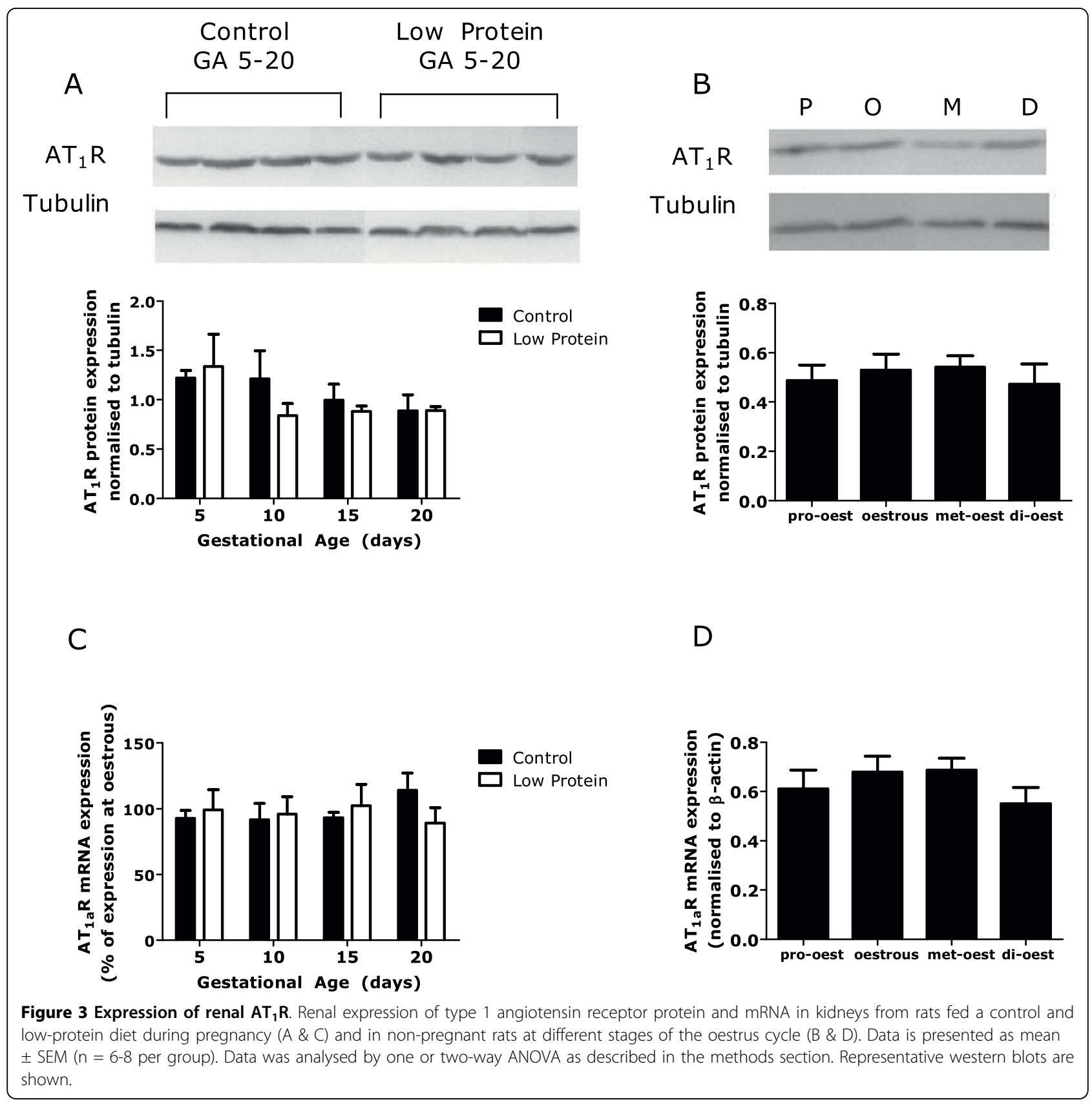

The observed down-regulation of AQP2 mRNA and protein expression during pregnancy is in direct contrast to evidence published previously demonstrating a pregnancy-related up-regulation of AQP2 in renal papillae $[44,45]$. Segmental differences in aquaporin protein expression in the kidney have been reported by other groups. The utilization of whole kidney samples for analyses was an important limitation of the present study. The increase in AQP2 in pregnancy reported by Ohara et al., [44] occurred in the inner medulla and may not be detectable in whole kidney studies. Furthermore, it is possible that translocation of AQP2 from the cytosol to the cell membrane may have interfered with protein extraction and skewed our analyses. It would therefore be more informative to consider the relative distributions of cytosolic and apical AQP2 in future studies and this would be best accomplished through immunohistochemical analysis.

Interestingly, in the study of Ohara et al., [44], the upregulation of AQP2 was observed in the absence of a detectable increase in plasma AVP, but with a role for vasopressin receptor indicated by antagonist studies. 


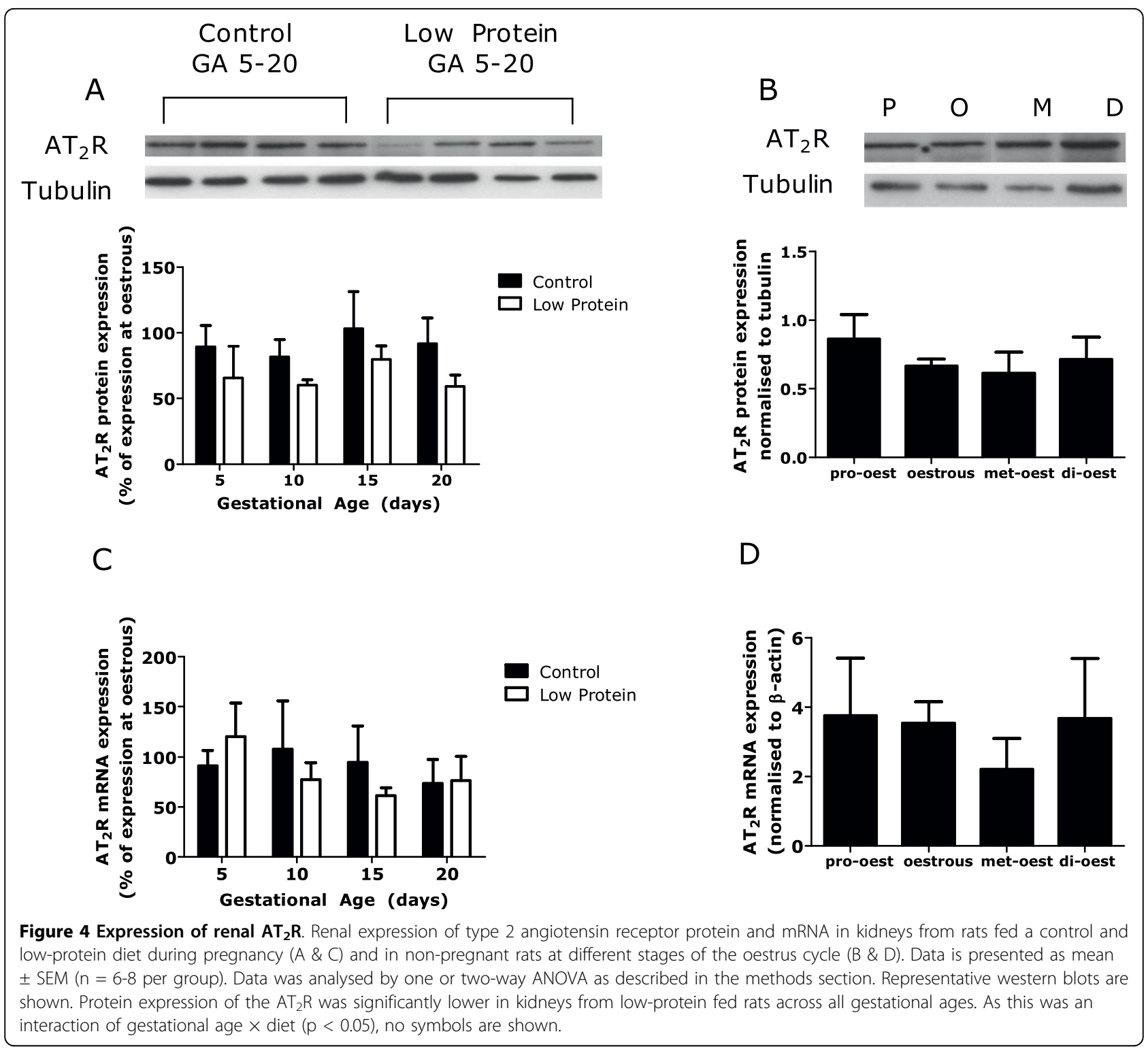

Similarly, increased urinary excretion of AQP2 in human pregnancy occurred in the absence of increased circulating AVP concentrations [46]. Given the apparent dissociation between AVP and AQP2 expression in these studies and the contrasting results observed in the current study and that of Ohara et al. [44], further work investigating the regulation of AQP2 expression and shuttling is required before its involvement in the enhanced water reabsorption during pregnancy can be fully understood. AQP3 and AQP4 are both present in the basolateral plasma membrane of collecting duct principal cells [47] and represent exit pathways for water reabsorbed apically via AQP2. The protein expression of these aquaporins remained unaffected by pregnancy per se, suggesting that the key regulatory events occur at the apical plasma membrane where the abundance of AQP2 protein creates a "bottleneck" for water reabsorption.

\section{Effects of a low protein diet}

In contrast to previous literature [16,17], feeding a lowprotein diet to pregnant rats did not have a statistically significant effect on plasma or blood volume expansion during pregnancy. However, a trend towards delayed volume expansion was noted at day 15 of pregnancy. The study by Rosso \& Streeter [16] used a more severe protein restriction (6\% versus $25 \%$ casein) than that used in the current study (9\% versus $18 \%$ casein), and the latter may not have been sufficient to impact significantly on plasma volume expansion. However, a 


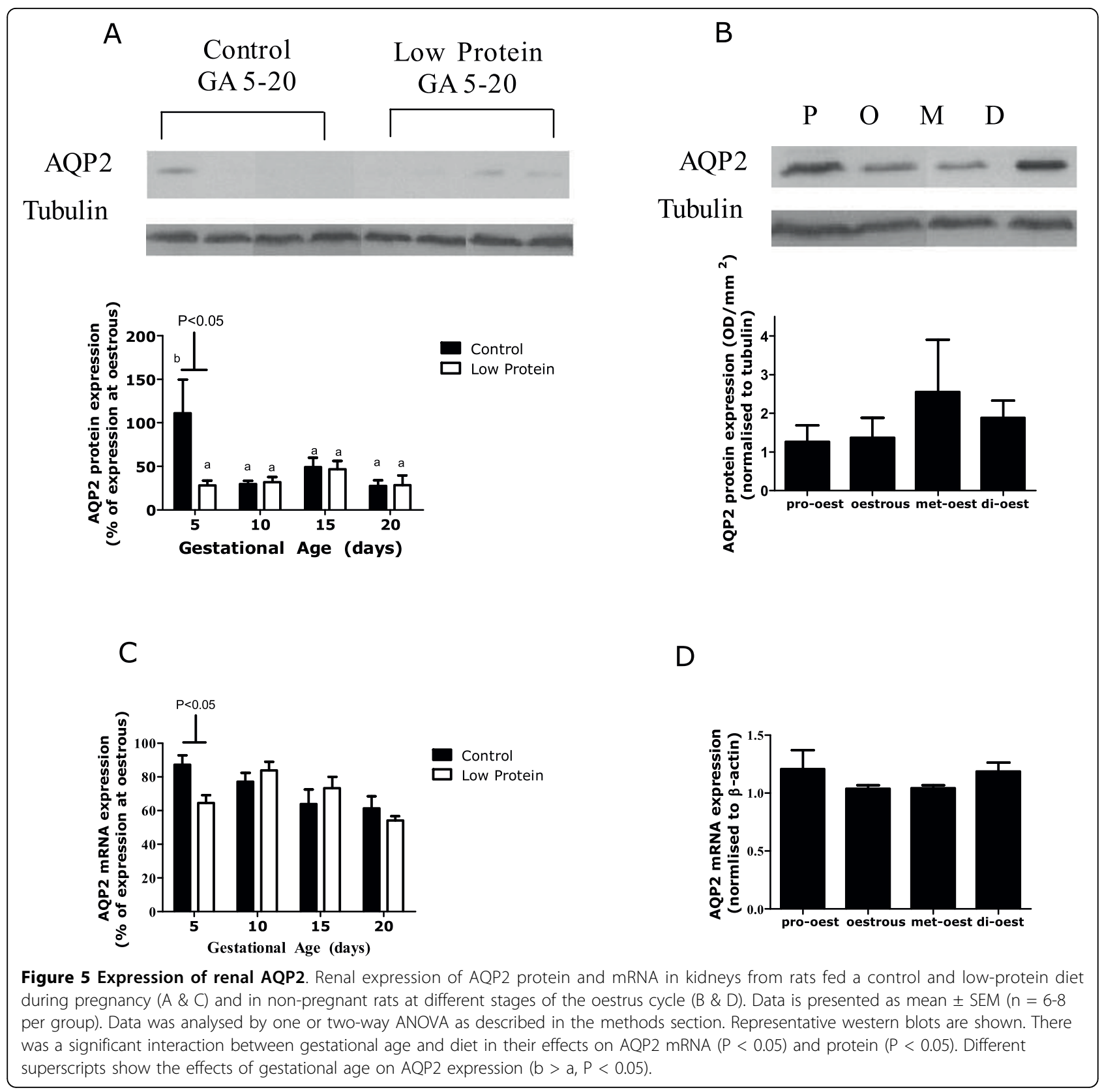

previous study using the same experimental dietary formulations as the current study did suggest a significant reduction in plasma volume expansion at day 20 of pregnancy [17]. In the current study, the relative reduction in creatinine clearance and the alterations in expression of key mediators of renal fluid homeostasis in response to a low-protein diet do provide further evidence that the regulatory systems involved in plasma volume expansion are susceptible to maternal protein restriction. However, the impact of the protein restriction was subtle and considerably less than expected. Our findings therefore suggest that maternal adaptation to pregnancy is less sensitive to protein restriction than has been previously inferred [16,17], and that only severe undernutrition has major influence on these processes.

The expression of $\mathrm{AT}_{2} \mathrm{R}$ protein was significantly decreased in low-protein fed rats throughout pregnancy. Enhanced $\mathrm{AT}_{2} \mathrm{R}$-mediated vascular relaxation pathways have been implicated in the systemic vasodilation of pregnancy, including increased expression and activity of endothelial $\mathrm{AT}_{2} \mathrm{R}$ [48] and involvement in the vasodilation of the uterine artery [49]. As a candidate for mediating counter-regulatory vasodilation in response to 


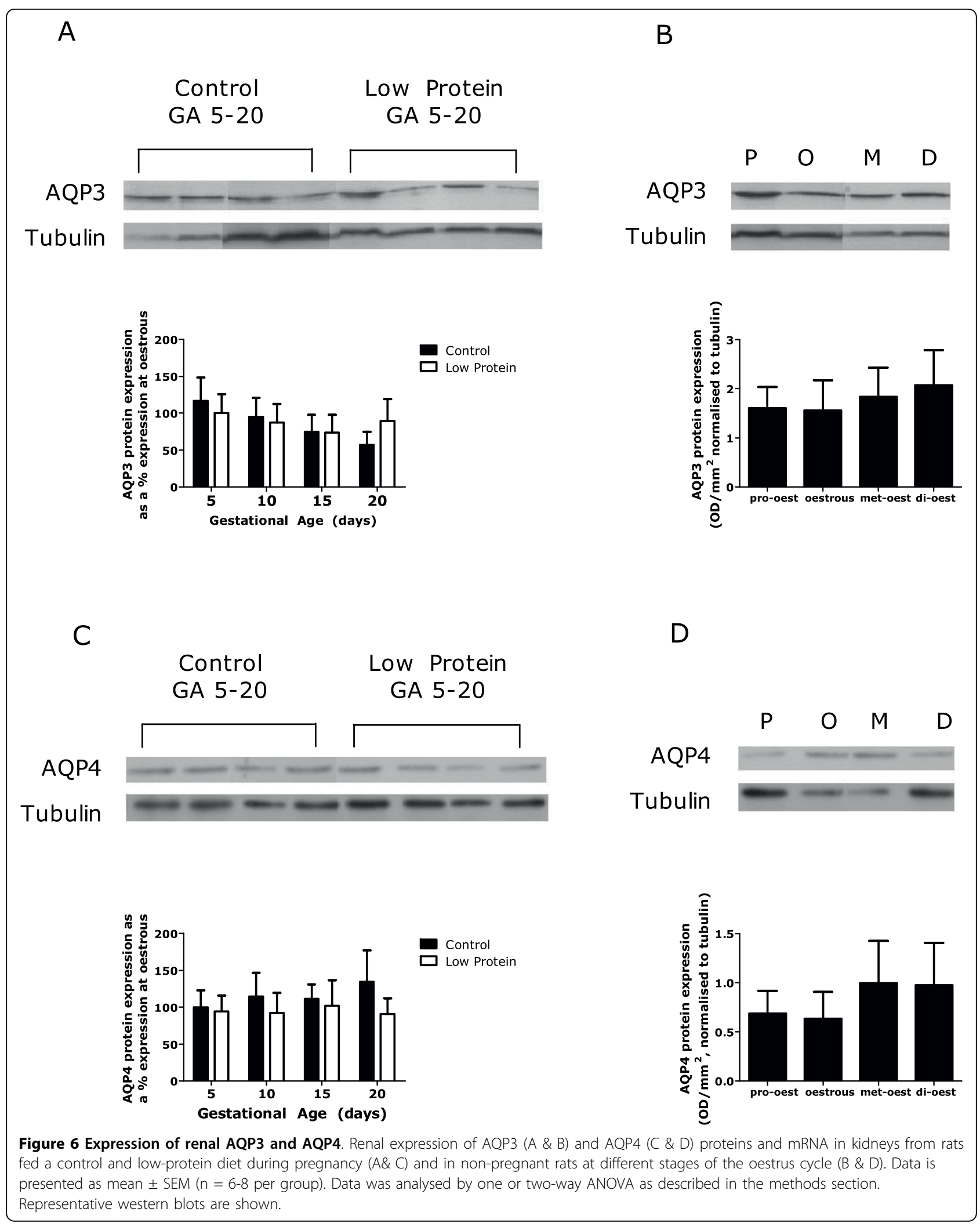


AngII in pregnancy, disruption of $\mathrm{AT}_{2} \mathrm{R}$ receptor expression may be involved in inadequate vascular adaptation to pregnancy. Interestingly, a previous study has shown vascular relaxation in response to an endotheliumdependent vasodilator to be impaired in mesenteric arteries of pregnant rats fed a 9\% protein diet [50]. This study adds to this previous literature by indicating a role for intra-renal $\mathrm{AT}_{2} \mathrm{R}$ in mediating altered haemodynamic function in pregnant rats fed a low-protein diet. In addition to the alterations in $\mathrm{AT}_{2} \mathrm{R}$ expression, the down-regulation of AQP2 occurred earlier in low-protein fed rats. Given the prevailing evidence of reduced or, as observed here, delayed plasma volume expansion in low-protein-fed dams, we had hypothesised that this would occur and suggest that this signifies a reduced capacity for water reabsorption in low-protein-fed rats.

\section{Conclusion}

To conclude, this study has demonstrated that no change in expression of intrarenal $\mathrm{AT}_{1} \mathrm{R}$ or $\mathrm{AT}_{2} \mathrm{R}$ proteins occurs during pregnancy. Surprisingly, a down-regulation of AQP2 was observed and the role of this water channel during pregnancy remains unclear. A significant down-regulation of $\mathrm{AT}_{2} \mathrm{R}$ protein expression was observed in low protein fed animals alongside a relative decrease in creatinine clearance, providing evidence that regulatory systems involved in plasma volume expansion are susceptible to maternal nutrient restriction. However, the impact of protein restriction on maternal blood volume expansion was relatively minor, suggesting that adaptive responses are able to compensate for variation in nutritional status.

\section{Abbreviations}

AMP: adenosine monophosphate; $A Q P$ : aquaporin; $A T_{1} R$ : angiotensin II type 1 receptor; $A_{2} R$ : angiotensin II type 2 receptor; AVP: arginine-vasopressin; EDTA: ethylenediaminetetraacetic acid; EPRF: effective renal plasma flow; GA: gestational age; GFR: glomerular filtration rate; RAAS: renin-angiotensinaldosterone system.

\section{Acknowledgements}

RC was funded by a PhD studentship from the BBSRC. We would like to acknowledge Dr David Marples (University of Leeds) for donating the polyclonal antibody to rat AQP2 and the technical support of Mr Richard Plant for blood volume determination and Dr Nigel Kendall for haematology analyses. We also thank Mrs Carol Armett and Sarah Kirkland for their care of their animals.

\section{Author details \\ ${ }^{1}$ School of Biosciences, University of Nottingham, Sutton Bonington Campus, Loughborough, LE12 5RD, UK. ${ }^{2}$ School of Veterinary Medicine and Science, University of Nottingham, Sutton Bonington Campus, Loughborough, LE12 5RD, UK}

\section{Authors' contributions}

RC carried out the animal experiments and analyses of gene and protein expression. SLE participated in the design of the study and the drafting of the manuscript. AM contributed to the design of the study and the analyses of AQP expression. SM conceived the study, participated in its design and co-ordination and helped to draft the manuscript. All authors read and approved the final manuscript.

\section{Competing interests}

The authors declare that they have no competing interests.

Received: 16 July 2010 Accepted: 31 August 2010

Published: 31 August 2010

\section{References}

1. Salas SP, Marshall G, Gutierrez B, Rosso P: Time course of maternal plasma volume and hormonal changes in women with preeclampsia or fetal growth restriction. Hypertension 2006, 47:203-208.

2. Taylor DJ, Lind T: Red-cell mass during and after normal-pregnancy. BJOG 1979, 86:364-370.

3. Duvekot JJ, Cheriex EC, Pieters FAA, Menheere P, Schouten HJA, Peeters LLH: Maternal volume homeostasis in early-pregnancy in relation to fetal growth restriction. Obstet Gynecol 1995, 85:361-367.

4. Salas SP, Rosso P: Plasma volume, renal function, and hormonal levels in pregnant women with idiopathic fetal growth restriction or preeclampsia. Hypertens Pregnancy 1998, 17:69-79.

5. Atherton JC, Dark JM, Garland HO, Morgan MRA, Pidgeon J, Soni S: Changes in water and electrolyte balance, plasma volume and composition during pregnancy in the rat. J Physiol 1982, 330:81-93.

6. Duvekot JJ, Cheriex EC, Pieters FAA, Menheere P, Peeters LLH: Earlypregnancy changes in hemodynamics and volume homeostasis are consecutive adjustments triggered by a primary fall in systemic vascular tone. Am J Obstet Gynecol 1993, 169:1382-1392.

7. Al Kadi $H$, Nasrat $H$, Pipkin FB: A prospective, longitudinal study of the renin-angiotensin system, prostacyclin and thromboxane in the first trimester of normal human pregnancy: association with birthweight. Human Reprod 2005, 20:3157-3162.

8. Schrier RW, Cadnapaphornchai MA, Ohara M: Water retention and aquaporins in heart failure, liver disease and pregnancy. J Royal Soc Med 2001, 94:265-269.

9. Chapman AB, Abraham WT, Zamudio S, Coffin C, Merouani A, Young D, Johnson A, Osorio F, Goldberg C, Moore LG, Dahms T, Schrier RW: Temporal relationships between hormonal and hemodynamic changes in early human pregnancy. Kid Int/ 1998, 54:2056-2063.

10. Bekheirnia MR, Schrier RW: Pathophysiology of water and sodium retention: edematous states with normal kidney function. Curr Op Pharmacol 2006, 6:202-207.

11. Paller MS, Gregorini G, Ferris TF: Pressor responsiveness in pseudopregnant and pregnant rats - role of maternal factors. Am Physiol 1989, 257:R866-R871.

12. Chapman AB, Zamudio S, Woodmansee W, Merouani A, Osorio F Johnson A, Moore LG, Dahms T, Coffin C, Abraham WT, Schrier RW: Systemic and renal hemodynamic changes in the luteal phase of the menstrual cycle mimic early pregnancy. Am J Physiol 1997, 273:F777-F782.

13. Van Mieghem T, van Bree R, Van Herck E, Deprest J, Verhaeghe J: Insulinlike growth factor-II regulates maternal hemodynamic adaptation to pregnancy in rats. Am J Physiol 2009, 297:R1615-R1621.

14. Hytten F: Blood-volume changes in normal-pregnancy. Clin Haematol 1985, 14:601-612.

15. Sands JM, Naruse M, Jacobs JD, Wilcox JN, Klein JD: Changes in aquaporin2 protein contribute to the urine concentrating defect in rats fed a lowprotein diet. J Clin Invest 1996, 97:2807-2814.

16. Rosso P, Streeter MR: Effects of food or protein restriction on plasmavolume expansion in pregnant rats. J Nutr 1979, 109:1887-1892.

17. Welham SJM, Wheeler T, Langley-Evans SC: Maternal plasma volume expansion is modulated in early pregnancy by a low protein diet in the rat. Clin Sci 1998, 94:M15.

18. McMullen S, Mostyn A: Animal models for the study of the developmental origins of health and disease. Proc Nutr Soc 2009, 68:306-320.

19. Langley-Evans SC, Jackson AA: Intrauterine programming of hypertension: nutrient-hormone interactions. Nutr Reviews 1996, 54:163-169.

20. Langley-Evans SC, McMullen S: Developmental origins of adult disease. Med Princ Pract 2010, 19:87-98.

21. Schrier RW: Water and sodium retention in edematous disorders: Role of vasopressin and aldosterone. Am J Med 2006, 119:S47-S53. 
22. Langley-Evans SC, Gardner DS, Jackson AA: Association of disproportionate growth of fetal rats in late gestation with raised systolic blood pressure in later life. J Reprod Fertil 1996, 106:307-312.

23. Bowers $L D$, Wong $E T$ : Kinetic serum creatinine assays. 2. A criticalevaluation and review. Clin Chem 1980, 26:555-561.

24. Blair ML, Mickelsen D: Plasma protein and blood volume restitution after hemorrhage in conscious pregnant and ovarian steroid-replaced rats. Am J Physiol 2006, 290:R425-R434.

25. Bradford MM: Rapid and sensitive method for quantitation of microgram quantities of protein utilizing principle of protein-dye binding. Anal Biochem 1976, 72:248-254.

26. Mobasheri A, Wray S, Marples D: Distribution of AQP2 and AQP3 water channels in human tissue microarrays. J Mol Histol 2005, 36:1-14.

27. Floyd RV, Mason SL, Proudman CJ, German AJ, Marples D, Mobasheri A: Expression and nephron segment-specific distribution of major renal aquaporins (AQP1-4) in Equus caballus, the domestic horse. Am J Physiol 2007, 293:R492-R503.

28. McMullen S, Langley-Evans SC: Maternal low-protein diet in rat pregnancy programs blood pressure through sex-specific mechanisms. Am J Physiol 2005, 288:R85-90.

29. Ferreira VM, Gomes TS, Reis LA, Ferreira AT, Razvickas CV, Schor N, Boim MA: Receptor-induced dilatation in the systemic and intrarenal adaptation to pregnancy in rats. Plos One 2009, 4:e4845.

30. Bedard S, Sicotte B, St-Louis J, Brochu M: Modulation of body fluids and angiotensin II receptors in a rat model of intra-uterine growth restriction. J Physiol 2005, 562:937-950.

31. Rogers UL, Mitchell AR, Maric C, Sandberg K, Myers A, Mulroney SE: Effect of sex hormones on renal estrogen and angiotensin type 1 receptors in female and male rats. Am J Physiol 2007, 292:R794-R799.

32. Kalenga MK, De Gasparo M, Thomas K, De Hertogh R: Down-regulation of angiotensin AT1 receptor by progesterone in human placenta. J Clin Endocrinol Metab 1996, 81:998-1002.

33. Conrad KP: Mechanisms of renal vasodilation and hyperfiltration during pregnancy. J Soc Gynecol Invest 2004, 11:438-448.

34. Gant NF, Daley GL, Chand S, Whalley PJ, Macdonal PC: Study of angiotensin-II pressor response throughout primigravid pregnancy. J Clin Invest 1973, 52:2682-2689.

35. Baker PN, Pipkin FB, Symonds EM: Longitudinal-study of platelet angiotensin-II binding in human-pregnancy. Clin Sci 1992, 82:377-381.

36. Masilamani $S$, Baylis $C$ : The renal vasculature does not participate in the peripheral refractoriness to administered angiotensin II (All) in the late pregnant (LP) rat. J Am Soc Nephrol 1992, 3:566.

37. Masilamani $S$, Hobbs GR, Baylis $C$ : The acute pressure natriuresis response blunted and the blood pressure response reset in the normal pregnant rat. Am J Obstet Gynecol 1998, 179:486-491.

38. Ferreira VM, Gomes TS, Reis LA, Ferreira AT, Razvickas CV, Schor N, Boim MA: Receptor-induced dilatation in the systemic and intrarenal adaptation to pregnancy in rats. Plos One 2009, 4:e4845.

39. Debrah DO, Novak J, Matthews JE, Ramirez RJ, Shroff SG, Conrad KP: Relaxin is essential for systemic vasodilation and increased global arterial compliance during early pregnancy in conscious rats. Endocrinology 2006, 147:5126-5131.

40. Fushimi K, Uchida S, Hara Y, Hirata Y, Marumo F, Sasaki S: Cloning and expression of apical membrane water channel of rat-kidney collecting tubule. Nature 1993, 361:549-552.

41. Nielsen S, Chou CL, Marples D, Christensen El, Kishore BK, Knepper MA: Vasopressin increases water permeability of kidney collecting duct by inducing translocation of aquaporin-CD water channels to plasmamembrane. Proc Natl Acad Sci USA 1995, 92:1013-1017.

42. Yamamoto T, Sasaki S, Fushimi K, Kawasaki K, Yaoita E, Oota K, Hirata Y, Marumo F, Kihara I: Localization and expression of a collecting duct water channel, aquaporin, in hydrated and dehydrated rats. Exp Nephrol 1995, 3:193-201.

43. Saito T, Ishikawa SE, Sasaki S, Fujita N, Fushimi K, Okada K, Takeuchi K, Sakamoto A, Ookawara S, Kaneko T, Marumo F: Alteration in water channel AQP-2 by removal of AVP stimulation in collecting duct cells of dehydrated rats. Am J Physiol 1997, 272:F183-F191.

44. Ohara M, Martin PY, Xu DL, St John J, Pattison TA, Kim JK, Schrier RW: Upregulation of aquaporin 2 water channel expression in pregnant rats. J Clin Invest 1998, 101:1076-1083.
45. Abreu N, Tardin JC, Boim MA, Campos RR, Bergamaschi CT, Schor N: Hemodynamic parameters during normal and hypertensive pregnancy in rats:evaluation of renal salt and water transporters. Hypertens Pregnancy 2008, 49-63.

46. Buemi M, D'Anna R, Di Pasquale G, Floccari F, Ruello A, Aloisi C, Leonardi I, Frisina N, Corica F: Urinary excretion of aquaporin-2 water channel during pregnancy. Cell Physiol Biochem 2001, 11:203-208.

47. Nielsen S, Frokiaer J, Marples D, Kwon TH, Agre P, Knepper MA: Aquaporins in the kidney:From molecules to medicine. Physiol Rev 2002, 82:205-244.

48. Stennett AK, Qiao XY, Falone AE, Koledova W, Khalil RA: Increased vascular angiotensin type 2 receptor expression and NOS-mediated mechanisms of vascular relaxation in pregnant rats. Am J Physiol 2009, 296:H745-H755.

49. Hannan RE, Davis EA, Widdop RE: Functional role of angiotensin II AT(2) receptor in modulation of AT(1) receptor-mediated contraction in rat uterine artery:involvement of bradykinin and nitric oxide. $\mathrm{Br} J$ Pharmacol 2003, 140:987-995

50. Koumentaki A, Anthony F, Poston L, Wheeler T: Low-protein diet impairs vascular relaxation in virgin and pregnant rats. Clin Sci 2002, 102:553-560.

doi:10.1186/1477-7827-8-105

Cite this article as: Cornock et al.: The impact of maternal protein restriction during rat pregnancy upon renal expression of angiotensin receptors and vasopressin-related aquaporins. Reproductive Biology and Endocrinology 2010 8:105.

\section{Submit your next manuscript to BioMed Central and take full advantage of:}

- Convenient online submission

- Thorough peer review

- No space constraints or color figure charges

- Immediate publication on acceptance

- Inclusion in PubMed, CAS, Scopus and Google Scholar

- Research which is freely available for redistribution

Submit your manuscript at www.biomedcentral.com/submit
C Biomed Central 